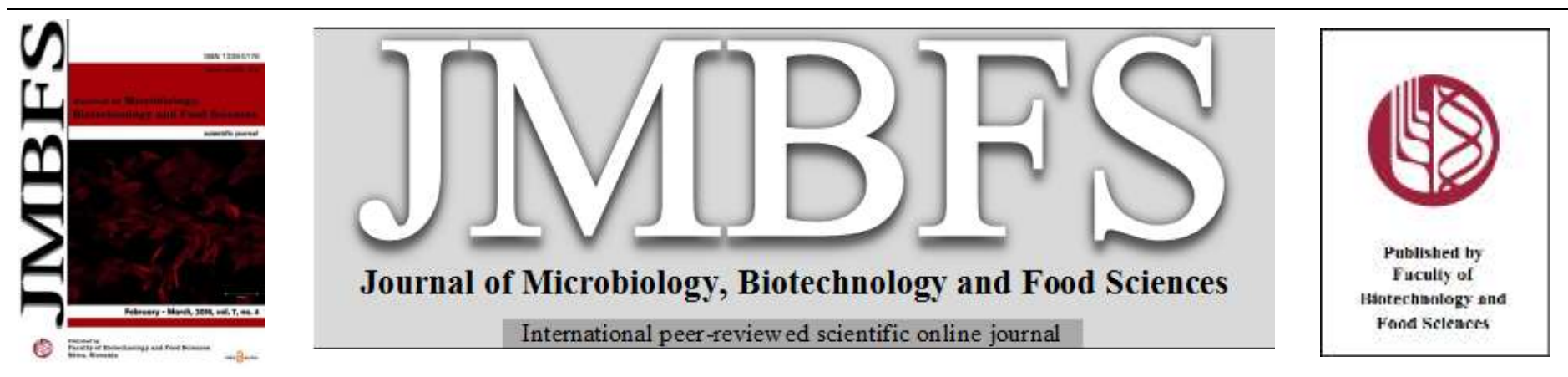

\title{
GENETIC DIVERSITY OF SLOVAK ORIGIN GEESE POPULATIONS
}

\author{
Slavomir Mindek ${ }^{1}$, Cyril Hrnčár ${ }^{2}$, Ján Weis ${ }^{2}$,Anna Trakovická ${ }^{3}$,Silvia Mindeková ${ }^{4}$ \\ Address(es): Ing. Slavomír Mindek, PhD., \\ ${ }^{1}$ Department of Veterinary Sciences, Slovak University of Agriculture, Nitra, Slovak Republic. \\ ${ }^{2}$ Department of Poultry Science and Small Animal Husbandry, Slovak University of Agriculture, Nitra, Slovak Republic. \\ ${ }^{3}$ Department of Genetics and Breeding Biology, Slovak University of Agriculture, Nitra, Slovak Republic. \\ ${ }^{4}$ Breeding Services of the Slovak Republic, Breeding Purpose Centre - Laboratory of Genetics Nitra, Slovak Republic.
}

*Corresponding author: slavomir.mindek@uniag.sk

doi: 10.15414/jmbfs.2018.7.4.416-420

\section{ARTICLE INFO}

Received 12. 10. 2017

Revised 17. 11. 2017

Accepted 5. 12. 2017

Published 1. 2. 2018

Regular article

oren (6) access

\section{ABSTRACT}

The genetic diversity was assessed in 102 individual genotypes in two national goose breeds Suchovska and Slovak and one extinct production crossbreed Tesedik Goose. A total of 40 alleles were found across 6 detected microsatellite loci with a mean number of 6.67 alleles per locus. The mean observed heterozygosity in total population was 0.40 . The degree of inbreeding of Suchovska, Slovak and Tesedik calculated as a mean $\mathrm{F}_{\mathrm{IS}}$ was $0.15,0.11$ and 0.07 respectively. The populations were low differentiated, with a mean $\mathrm{F}_{\mathrm{ST}}$ value 0.075 in total population. The highest genetic distance was estimated between Slovak and Tesedik (0.087). The results of genetic diversity showed that Suchovska and Slovak Goose satisfies criteria for endangered breeds.

Keywords: genetic diversity, genetic distance, microsatellite, goose/geese

\section{INTRODUCTION}

Genetic diversity study is an important requirement for understanding genetic variation within and among breeds, strains and lines and future animal breeding strategies (Lenstra et al., 2012), also can be used to identify genetically vulnerable breeds (Wilkinson et al., 2012), for understanding phenotypic variation (FAO, 2007) and for reconstructing the history of livestock (Groeneveld et al., 2010).

In Slovakia exist two recognize national goose breeds Suchovska and Slovak, as a combination of old indigenous breeds and foreign introduced breeds and extinct crossbreed Tesedik Goose. The Suchovska Goose is a result of crossbreeding of local yellow fathering geese with French (Toulouse, Landes) and German (Pomorany, Steinbach) geese, originated at the end of the 1980`s in the village of Suchá nad Parnou and recognized as a breed in 1995 (Kadlečík et al., 2004). It required breeding geese of bigger body frame, firm constitution and of compact and solid body. The geese are by suitable for pasture and for small farming because of the preservation of the clucking instinct of the geese (Weis and Hrnčár, 2007).

The Slovak Goose was created from regional breeds from South-Western Slovakia. Regional German and Hungarian types of goose were used during the breeding process. A year of recognition and initial numbers of birds are unknown (Kadlečík et al., 2004). The aim of breeding was to create a medium weight triple purpose (meat, liver, feather) geese suitable for corn areas, strong resistant geese with a good pasturing ability and with preserved clucking instinct achieved (Weis and Hrnčár, 2007).

Tesedik Goose was created as a commercial crossbreed on the basis of three crossbreed lines: Ivagees (SVK), 2891 (CZE), Babati (HU), recognized in 2002. The aim of breeding programme were preservation and revitalization of origin Ivagees line as a crossbreed of Slovak, Landes, Italian and Rhine Goose. From 1994 in pedigree breeding reproduction and selections were in closed herd turnover (Mindek, 2001).

The main tool in the characterization of the genetic diversity of farm animals is DNA polymorphism analysis of microsatellite loci (Simianer, 2006). Currently there are known same microsatellite markers isolated and evaluated in the wild form of geese as greylag goose Anser anser (Wieß et al., 2008), Canada goose Branta canadensis L. (Cathey et al., 1998), swan goose Anser cygnoides L. (Tu et al., 2006, Li et al., 2007), white-fronted goose Anser albifrons (Fields et al. 1997), pink-footed goose Anser brachyrhynchus (Noreikiene, 2012), Anser fabalis (Kleven et al., 2016). Anatidae specific microsatellite markers for study of genetic diversity were used in Chinese (Liu et al., 2006; Tu et al., 2006; Li et al., 2007; Cao et al., 2014), Hungarian, Embden (Aliczky, 2007) and Zatorska (Andres and Kapkowska, 2011) domestic goose breeds.

The objective if this study was preliminary characterization of the levels of the genetic diversity of two critically endangered and one extinct national breeds of goose, using the microsatellite loci analysis.

\section{MATERIAL AND METHODS}

Samples for analysis were taken from 102 geese, included Suchovska $(\mathrm{n}=32)$, Slovak $(n=20)$ and Tesedik $(n=50)$ Goose. Samples from Suchovska and Slovak Goose were collected on Nationwide Exhibition of Animals in 2003. Birds came from different breeders, predominantly from west part of Slovakia. Samples from Tesedik Goose were collected from pedigree breeding in 2005. Blood samples were used to isolated genomic DNA followed the protocol of Wizard Genomic DNA Purification Kit (Promega).

For diversity studies were used six Anatidae species-specific microsatellite markers (Aal $\mu 1$, Bca 1 1, CKW21, TTUCG5, Ans2 and Ans25). Genotyping was conducted using standard laboratory procedure for PCR. Primers for PCR amplification for loci Ans2 and Ans25 (Weiß et al., 2008) were designed for greylag goose (Anser anser), TTUCG5 (Cathey et al., 2006) and Bca 1 (Buchholz, 1998) were designed for Canada goose (Branta canadensis L.), Aalu1 (Fields, 1997) and CKW21 (Liu et al., 2006), were designed for swan (Anser cygnoides L.) and white fronted (Anser albifrons) goose respectively (Table 1). 
Table 1 Characteristic of microsatellite loci

\begin{tabular}{|c|c|c|c|c|c|}
\hline Locus & Source species & Ref. & $\begin{array}{l}\text { Repeat } \\
\text { motif }\end{array}$ & $\begin{array}{c}\text { Primer sequence } \\
5^{\prime}-3^{\prime} \\
\end{array}$ & $\begin{array}{l}\text { Allele size } \\
\text { range (bp) }\end{array}$ \\
\hline TTUCG5 & Branta canadensis & a & TCTAT & $\begin{array}{l}\text { GGGTGTTTTCCAACTCAG } \\
\text { CACTTTCСТTACСTCATCTTG }\end{array}$ & $176-288$ \\
\hline CKW21 & Anser cygnoides & $\mathrm{b}$ & $(\mathrm{TTA})_{10}$ & $\begin{array}{l}\text { CAAGGTAGTCATAAACCCAGAACA } \\
\text { ACAAAACTAATGGCAGGAAAC }\end{array}$ & $351-379$ \\
\hline Aal $\mu 1$ & Anser albifrons & $\mathrm{c}$ & TG & $\begin{array}{l}\text { CATGCGTGTTTAAGGGGTAT } \\
\text { TAAGACTTGCGTGAGGAATA }\end{array}$ & $85-89$ \\
\hline Ans 25 & Anser anser & d & $(\mathrm{GT})_{18}$ & $\begin{array}{l}\text { CACTTATTAATGGCACTTGAAA } \\
\text { GTTCTCTTGTCACAACTGGA }\end{array}$ & $261-267$ \\
\hline Ans2 & Anser anser & $\mathrm{d}$ & $(\mathrm{AG})_{17}$ & $\begin{array}{l}\text { TTCTGTGCAGGGGCGAGTT } \\
\text { AGGGAACCGATCACGACATG }\end{array}$ & $207-228$ \\
\hline Вса 1 & Branta canadensis & $\mathrm{e}$ & $(\mathrm{TA})_{15}(\mathrm{CA})$ & $\begin{array}{l}\text { TGCTTTTTACCCCCAGTGTTCT } \\
\text { AGAATCTGCTATATTATTTCCAGCTC }\end{array}$ & $114-124$ \\
\hline
\end{tabular}

Ref.: ${ }^{\mathrm{a} C a t h e y ~}$ et al. (2006), ${ }^{\mathrm{b}} \mathrm{Liu}$ (2006), ${ }^{\mathrm{c}}$ Fields (1997), ${ }^{\mathrm{d}}$ Weiß et al. (2008), ${ }^{\mathrm{e}}$ Buchholz (1998)

Six pairs of primers were amplified in one multiplex PCR reaction (1U AmpliTaqGold). PCR amplification was performed on a thermal cycler MJ Research (anneling $59^{\circ} \mathrm{C} / 60$ s., 35 cycles). Amplified PCR products were electrophoresed on sequencer ABI 310 (Applied Biosystems). The size of the analyzed DNA fragments were determined in base pairs using computer package GeneScan v.3.7 (Applied Biosystems), by comparing to an internal size standard (LIZ 500, Applied Biosystems).

The total number of alleles, the average number of alleles per locus, expected and observed heterozygosity and polymorphic information content (PIC) of microsatellite loci (Botstein et al., 1980; Weir, 1996) were estimated using PoweMarker 3.25 (Liu and Muse, 2005). Number of effective alleles and privat (breed-specific) alleles were calculated by GenAIEx software (Peakall and Smouse, 2006). The extent of genotyping linkage disequilibrium (LD) between pairs of loci in each group of breeds by performing probability test and deviations from Hardy-Weinberg equilibrium (HWE) across all loci for each population were performed by estimation of exact P-value by the Markov chain method using GENEPOP 4.2 software (Rousset, 2008).

The effective population size was estimated by Simon and Buchenauer (1993):

$N e=4 * M * F /(M+F)$

where: $\mathrm{M}$ is the number of males, $\mathrm{F}$ is the number of females.

The ratio of the effective population size to census population size $(\mathrm{Ne} / \mathrm{N})$ is an indicator of the extent of genetic variation expected in a population. Male: female ratio $(\mathrm{Nm} / \mathrm{Nf})$ is defined as the number of breeding males upon the number of breeding females in a population. Population genetic differentiation was examined using pairwise population fixation index $\left(\mathrm{F}_{\mathrm{ST}}\right)$ values and F-statistics estimated over all populations for each locus, computed by GenAIEx software (Peakall and Smouse, 2006), within-population inbreeding coefficient ( $\left.F_{I S}\right)$ were computed using PowerMarker 3.25 (Liu and Muse, 2005). Nei's standard genetic distance with sample size correction from a small number of individuals (1978) and construction of a neighbor-joining (NJ) tree were performed by POPTREE 2 (Takezaki et al., 2010). To represent geometric relationship among the populations and individuals, a factorial component analysis (FCA) was applied using gene frequencies of all variable loci with Genetix4 (Belkhir et al., 1996-98)

\section{RESULTS AND DISCUSSION}

Genotyping in total population of 102 individuals for 6 polymorphic microsatellite loci a total of 40 different alleles were detected. The mean number of alleles was 6.67, with the range extending from 4.17 (Suchovska) to 4.67 (Tesedik). Number of effective alleles across all population range near 2, with a mean number of effective alleles 2.19. A total of 11 private (breed-specific) alleles were detected. Private alleles with a frequency $<0.1 \%$ occurred only in Slovak breed (Table 2).

Table 2 Genetic diversity

\begin{tabular}{|c|c|c|c|c|c|c|c|c|}
\hline Population & Sample size & $\begin{array}{l}\text { Mean No. of } \\
\text { allele }\end{array}$ & $\begin{array}{l}\text { Mean No. of } \\
\text { effect. allele }\end{array}$ & $\begin{array}{c}\text { No of } \\
\text { private } \\
\text { allele }^{1}\end{array}$ & $\begin{array}{l}\text { Mean expected } \\
\text { heterozyg. }\end{array}$ & $\begin{array}{c}\text { Mean } \\
\text { observed } \\
\text { heterozyg. }\end{array}$ & $\mathbf{L D}^{2}$ & $H_{W^{3}}$ \\
\hline Suchovska & 32 & 4.17 & 2.03 & $4 / 0$ & 0.38 & 0.33 & 5 & 1 \\
\hline Slovak & 20 & 4.33 & 2.33 & $4 / 2$ & 0.45 & 0.42 & 2 & 2 \\
\hline Tesedik & 50 & 4.67 & 2.21 & $3 / 0$ & 0.45 & 0.43 & 3 & 1 \\
\hline Total & 102 & 6.67 & 2.19 & $11 / 2$ & 0.46 & 0.40 & 6 & 3 \\
\hline
\end{tabular}

${ }^{1}$ total number of private alleles / number of alleles with a frequency $<0.1 \%$

${ }^{2}$ number of significant test of linkage disequilibrium (LD) out of 15 possible pairs of loci

${ }^{3}$ number of significant disequilibrium of Hardy-Weinberg test

The average expected heterozygosity over all loci ranged from 0.38 in Suchovska to 0.45 in Slovak and Tesedik, while observed heterozygosity varied from 0.33 in Suchovska to 0.43 in Slovak and Tesedik. Mean expected and observed heterozygosity over all loci and group were 0.46 and 0.40 respectively. In population significant deviations from HWE were revealed in TTUCG5, Ans2 and Bcau1 locus. In a total population LD was found in 6 out of 15 pairs of loci, with the highest number of locus-pairs with significant LD in Suchovska (5) breed (Table 2).

Table 3 Genetic diversity per loci in the total population

\begin{tabular}{cccccccccc}
\hline Locus & $\begin{array}{c}\text { No. } \\
\text { of obs. }\end{array}$ & $\begin{array}{c}\text { Genotype } \\
\text { No }\end{array}$ & $\begin{array}{c}\text { Major } \\
\text { Allele } \\
\text { Frequency }\end{array}$ & $\begin{array}{c}\text { Allele } \\
\text { No }\end{array}$ & $\begin{array}{c}\text { Expected } \\
\text { Heterozyg. }\end{array}$ & $\begin{array}{c}\text { Observed } \\
\text { Heterozyg. }\end{array}$ & PIC & Fis & Fst \\
\hline TTUCG5 & 102 & 32 & 0.23 & 13 & 0.84 & 0.73 & 0.82 & 0.081 & 0.081 \\
CKW21 & 100 & 12 & 0.76 & 7 & 0.41 & 0.39 & 0.39 & 0.011 & 0.070 \\
Aal $\mu 1$ & 102 & 6 & 0.84 & 3 & 0.27 & 0.23 & 0.26 & 0.069 & 0.136 \\
Ans25 & 102 & 7 & 0.63 & 4 & 0.54 & 0.51 & 0.48 & 0.005 & 0.083 \\
Ans2 & 102 & 10 & 0.84 & 7 & 0.28 & 0.23 & 0.27 & 0.154 & 0.042 \\
Bca 1 & 102 & 11 & 0.75 & 6 & 0.41 & 0.27 & 0.39 & 0.324 & 0.040 \\
Mean & 101.7 & 13.0 & 0.68 & 6.7 & 0.46 & 0.40 & 0.43 & 0.100 & 0.075 \\
\hline
\end{tabular}


Across all population the number of alleles per locus ranged from 3.0 (Aal $\mu 1)$ to 13 (TTUCG5). Major allele frequencies differed notably in their distribution in the different loci, ranging from 0.23 (TTUCG5) to 0.84 (Ans2, Aal $\mu 1$ ), with an average value 0.68 per locus. The number of observed genotype varied widely from 6 (Aal $\mu 1$ ) to 32 (TTUCG5), with an average value 13.0 per locus. In all estimated loci the observed heterozygosity is similar or lower to their expectation. The lowest and the greatest heterozygosity per locus was 0.23 (Aal $\mu 1$, Ans2) and 0.73 (TTUCG5) respectively, with an average value 0.40 . The estimated PIC ranged from 0.26 (Aal $\mu 1$ ) to 0.82 (TTUCG5), with a mean PIC value 0.43 (Table 3 ).

The Pairwise Population $F_{S T}$ Values between Suchovska and Slovak and between Slovak and Tesedik was 0.050 and 0.051 respectively. The $\mathrm{F}_{\mathrm{ST}}$ value among Suchovska and Tesedik was 0.038 . Mean genetic differentiation $\left(\mathrm{F}_{\mathrm{ST}}\right)$ estimated over all populations for each locus was 0.075 . All populations had positive within-population $\left(\mathrm{F}_{\mathrm{IS}}\right)$ estimates, where mean $\mathrm{F}_{\mathrm{IS}}$ values were 0.07 for Tesedik, 0.13 for Slovak and 0.15 for Suchovska. Mean F IS value in total population was 0.14 (Figure 1). Significant deficiency of heterozygotes occurred in locus

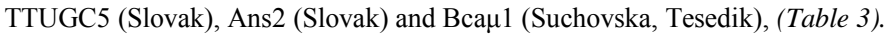
All estimated microsatellite loci were polymorphic as was published in previously studies (Aliczki 2007; Wieß et al. 2008; Andres and Kapkowska, 2011), with a varying number of alleles. The number of alleles detected in locus TTUCG5, Aal $\mu 1$, Bca 1 were similar as in other breeds (Bucholz et. al; 1998 Aliczki 2007; Andres and Kapkowska, 2011). Considerable lower number of detected alleles was in CKW21, Ans2 and Ans25 locus, compare to other published papers (Liu et al., 2006; Aliczki 2007; Wieß et al. 2008; Andres and Kapkowska, 2011). Barker (1994) suggested that microsatellite loci used in genetic distance studies should have more than four alleles in order to reduce the distance estimate standard error. The mean numbers of allele in some loci in this study does not meet this condition. At the same time, several private alleles across the breeds were found. On the other hand, private alleles are not applicable as breed markers due to low frequency. The existence of private allele can be explain by multi-origin of the breeds, little subsequent genetic exchange between them, or by genetic drift (Agha et al., 2008).

The mean expected heterozygosity across all population were similar as in other European geese (Aliczki et al., 2007; Andres and Kapkowska, 2011 Noreikiene $\boldsymbol{e t}$ al., 2012), but considerably lower than in Chinese breeds (Tu $\boldsymbol{e t}$ al., 2006; Li et al., 2007). The results of the expected heterozygosity were consistent with that of PIC. Over all population the mean observed heterozygosity within populations were lower than mean expected. The deficiency of heterozygotes was reflected in the considerably higher estimates of within-population inbreeding coefficient $\left(\mathrm{F}_{\mathrm{IS}}\right)$, than was reported in Hungarian breeds (Aliczki et al., 2007). Estimated number of alleles and level of heterozygosity as an available parameter to assess within breeds genetic diversity refer about low genetic diversity of Suchovska and Slovak breeds. These results point out to inbreeding caused by small number of individuals. In decade 20012010 the census population size of Suchovska and Slovak Goose varied widely, with highest numbers of individuals in 2005 (Suchovska 143, Slovak 83). But last five years the population size gradually decreases, which is related to the decline of the effective population size with it historically the lowest value (Suchovska 13.750 and Slovak 26.182) (Table 4).

The effective population size as the indicator of the amount of genetic variation present in the population confirms the low level of genetic variation in Slovak national goose breeds. At the same, the decrease of effective population size leads increases to extent of LD. Higher number of alleles and observed heterozygosity in Tesedik Goose points to higher genetic diversity compare with Slovak national goose breeds, caused by crossbreeding and high number of individuals.

Table 4 Census population size, effective population size and sex ratio per breed and year

\begin{tabular}{|c|c|c|c|c|c|c|c|c|c|}
\hline \multirow[b]{2}{*}{ Year } & \multicolumn{3}{|c|}{ Suchovska Goose } & \multicolumn{3}{|c|}{ Slovak Goose } & \multicolumn{3}{|c|}{ Tesedik Goose } \\
\hline & $\mathrm{Ne} / \mathrm{N}$ & $\mathrm{Ne}$ & $\mathbf{N m} / \mathbf{N f}$ & $\mathrm{Ne} / \mathrm{N}$ & $\mathrm{Ne}$ & $\mathbf{N m} / \mathbf{N f}$ & $\mathrm{Ne} / \mathrm{N}$ & $\mathrm{Ne}$ & $\mathbf{N m} / \mathbf{N f}$ \\
\hline 1996 & & & & & & & 5191 & 4312.898 & 0.417 \\
\hline 2001 & 72 & 57.778 & 0.417 & 34 & 28.235 & 0.385 & 2074 & 1697.213 & 0.399 \\
\hline 2002 & 82 & 74.976 & 0.478 & 68 & 59.529 & 0.547 & 1850 & 1509.224 & 0.402 \\
\hline 2003 & 67 & 63.642 & 0.625 & 52 & 49.231 & 0.634 & 1762 & 1441.056 & 0.405 \\
\hline 2004 & 122 & 98.098 & 0.415 & 75 & 62.187 & 0.386 & 1988 & 1631.378 & 0.400 \\
\hline 2005 & 143 & 120.280 & 0.407 & 83 & 68.241 & 0.430 & & & \\
\hline 2006 & 141 & 125.333 & 0.375 & 66 & 52.364 & 0.500 & & & \\
\hline 2007 & 140 & 120.686 & 0.422 & 64 & 53.438 & 0.458 & & & \\
\hline 2008 & 136 & 112.941 & 0.717 & 79 & 76.861 & 0.417 & & & \\
\hline 2009 & 114 & 105.018 & 0.436 & 79 & 66.835 & 0.562 & & & \\
\hline 2010 & 82 & 69.512 & 0.439 & 82 & 69.512 & 0.439 & & & \\
\hline 2011 & 47 & 43.404 & 0.477 & 65 & 56.862 & 0.567 & & & \\
\hline 2012 & 35 & 28.571 & 0.452 & 45 & 38.578 & 0.400 & & & \\
\hline 2013 & 31 & 25.548 & 0.464 & 41 & 35.512 & 0.409 & & & \\
\hline 2014 & 26 & 22.154 & 0.407 & 38 & 31.263 & 0.444 & & & \\
\hline 2015 & 19 & 17.684 & 0.400 & 35 & 28.571 & 0.583 & & & \\
\hline 2016 & 16 & 13.750 & 0.375 & 33 & 26.182 & 0.455 & & & \\
\hline
\end{tabular}

Wang et al. (1999) demonstrated that fitness declines with $\mathrm{Ne}$ of 50 because of detrimental mutations fixation despite natural selection. Meuwissen and Wooliams (1994) suggested, from theoretical predictions, that Ne between 30 and 250 is needed for natural selection to counteract inbreeding depression. According to Lynch et al. (1995), Ne should exceed 500 animals otherwise, this accumulation of slightly deleterious mutations will deem the population to extinction. It is important to monitor $\mathrm{Ne}$, because it can be smaller than expected due to any effect increasing variance of the family size of an animal (e.g. selection, unequal survival rates). A rapid strategy to minimize inbreeding would be therefore to maximize the effective population size in flocks and increase the male: female ratio in some breeds (Larivière $\boldsymbol{e t}$ al., 2011).

For reducing the inbreeding rate in population, the effective population size needs to be increased for which many strategies are. These can be equalization of family sizes (Wang, 1997), choice of parents (Cabarello and Toro, 2000) and various systems of breeding (Nomura and Yonezawa, 2000).

Genetic distance was calculated based on allelic frequencies in each breed, after 10000 permutation (Nei, 1978). The highest genetic distance was estimated between Slovak and Tesedik (0.087), compare to the smallest genetic distance between Suchovska and Tesedik (0.054). The Nei's genetic distance 0.064 point out small genetic distance between Suchovska and Slovak breeds. Based on Nei's genetic distance matrix Neighbor-Joining tree was constructed (Figure 1).
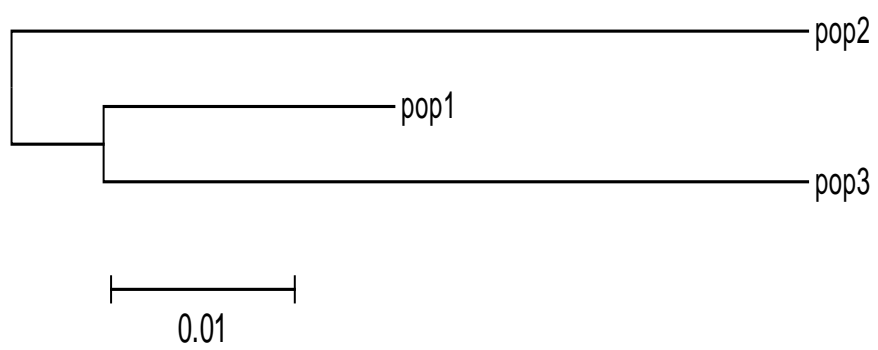

Figure 1 - Neighbor - Joining Tree

Legend: pop1 - Suchovska, pop2 - Slovak, pop3 - Tesedik

The mean genetic differentiation $\left(\mathrm{F}_{\mathrm{ST}}\right)$ estimated amongst the populations over all loci was lower with level comparable to Hungarian breeds (Aliczki et al., 2007) 
and other livestock species (Laval et al., 2000; Lawson-Handley et al., 2007). Values of all calculated pairwise population fixation index $\left(\mathrm{F}_{\mathrm{ST}}\right)$, that range near value 0.01 to 0.05 , shows a generally low level of genetic differentiation, with quite differences between populations.

Birds are crowded in relatively independent breed's cluster with a low deviation in both axes. A relatively large number of Suchovska individuals are incorporated in cluster of Tesedik Goose. Although Slovak Goose served as one of the progenitors of Tesedik, lower genetic distance was between Suchovska and Tesedik. Closer genetic relationship confirm with FCA analysis was caused probably by influence of Landes Goose that were introduced during crossbreeding of both Suchovska and Tesedik Goose. Although Suchovska and Slovak Goose are phenotypically different (wildly colored yellow, heavy Suchovska vs. white, medium weight Slovak), between breed diversity are considerable low. Close relationship among the population had obvious association with their historical relations and geographical distribution (Li et al., 2007), when the most goose breeds in Europe were originated from Anser anser (Tu et al., 2006). Moreover, Suchovska and Slovak have a common indigenous ancestor. On the other hand, the presence of private (breed-specific) alleles occurred over all estimated populations proved their genetic divergences.

To represent diversity that may correlate with geographical or genetic variability, a factorial component analysis (FCA) was applied using gene frequencies of all variable loci. The axe 1 explained $8.08 \%$ and axe 2 explained $7.32 \%$ of total variability (Figure 2).

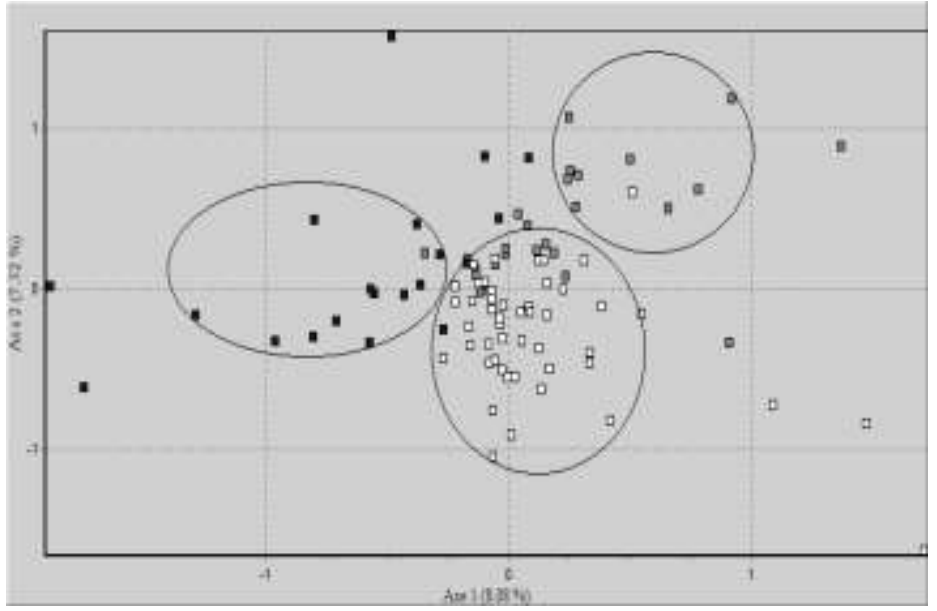

Figure 2 - Factorial correspondence analysis

Legend: Suchovska (grey), Slovak (black), Tesedik (white)

Compare to Chinese goose breeds (Tu et al., 2006; Li et al., 2007), genetic distance between evaluated populations are very low. Genetic distances were used to construct a between populations neighbor-joining tree (Figure 2), when Tesedik and Suchovska Goose branches are derived from Slovak Goose branch To represent geometric relationship among the birds and populations, a factorial component analysis (FCA) was applied (Figure 3).

\section{CONCLUSIONS}

The estimated low genetic diversity and uniqueness coupled with the low effective population size confirm that Suchovska and Slovak Goose are critically endangered and their preservation is required. In addition, these breeds are carriers of the gene pool of the indigenous local geese that no longer exist. For the future application, the increase a number of tested microsatellite markers is necessary.

Acknowledgements:We would like to acknowledge to Breeding Services of the Slovak Republic, s. e. for the help with laboratory part of this work. This work was financially supported by KEGA 006SPU-4/2014 and APVV-0636-11 projects.

\section{REFERENCES}

Agha, S.H., Pilla,F., Galal, S., Shaat, I., D’Andrea,M., Reale, S.,Abdelsalam, A.Z.A. \& Li, M.H. (2008). Genetic diversity in Egyptian and Italian Goat breeds measured with microsatellite polymorphism. Journal of Animal Breeding and Genetics, 125, 194-200. https://doi.org/10.1111/j.1439-0388.2008.00730.x

Aliczki, K.K. (2007). Examining genetic variability in ancient hungarian goose population with microsatellite. Ph.D. Thesis, University of Debrecen.

Andres, K. \& Kapkowska, E. (2011). Applicability of anatid and galliform microsatellite markers to the genetic diversity studies of domestic geese (Anser anser domesticus). BMC Research Notes 4, 65. Available from www.bimodcentral.com DOI: 10.1186/1756-0500-4-65

Barker, J.S.F. (1994). A global protocol for determining genetic distance among domestic livestock breeds. Proc. $5^{\text {th }}$ World Congress on Genetics Applied to Livestock Production, Geulph, Canada 21:516-523.

Belkhir, K., Borsa, P., Goudet, J., Chikhi, L. \& Bonhomme, F. (1996-1998). GENETIX, logiciel sous Windows TM pour la génétique des populations. Laboratoire du Génome et Populations, CNRS UPR 9060, Université de Montpellier II, Montpellier. France

Botstein, D., R.L. White, M. Skolnick, and R.W. Davis. 1980. Construction of a genetic linkage map in man using restriction fragment length polymorphism. American Journal of Human Genetics 32:314-331.

Buchholz, W.G., Pearce, J.M., Pierson, B.J., \& Scribner, K.T. (1985) Dinucleotide repeat polymorphisms in waterfowl (family Anatidae) characterization of a sex linked (Z-specific) and 14 autosomal loci. Animal Genetetics, 29, 323-325.

Cabarrelo, A. \& Toro, M. A. (2000). Interrelations between effective population size and other pedigree tools for management of conserved population. Genetic Research, 72, 331-343.

Cathey, J.C., Dewoody, J.A. \& Smith. L.M. (1998). Microsatellite markers in Canada geese (Branta canadensis). Journal of Heredity 89, 173-174.

Cao, Z.Z., Su, D., Zhao, Y.Y., Liu, M., Gao, M. \& Luan, X.H. (2014). Development of eight novel microsatellite markers for Huoyan geese. Genetic and Molecular Research, 13, 5562-5565. https://doi.org/10.4238/2014.july.25.10 FAO (2007) The state of the World's Animal Genetic Resources for Food and Agriculture. Rome: FAO, p. 38.

Fields, R.L. \& Scribner, K.T. (1997). Isolation and characterization of novel waterfowl microsatellite loci: cross-species comparisons and research applications. Molecular Ecology, 6, 199-202.

Gandini, G.C. \& Villa, E. (2003). Analysis of the cultural value of local livestock breeds: a methodology. Journal of Animal Breeding and Genetics, 120, 1-11. https://doi.org/10.1046/j.1439-0388.2003.00365.x

Groeneveld, L.F., Lenstra, J.A., Eding, H., Toro, M.A., Scherf, B., Pilling, D. Negrini, R., Finlay, E.K., Jianlin, H., Goeneveld, E., Weigend, S. \& GLOBALDIV Consortium. (2010). Genetic diversity in farm animals-review. Animal Genetics, 41, 6-31. https://doi.org/10.1111/j.1365-2052.2010.02038.x

Hrnčár, C., Gardiánová, I., Mindek, S., Weis, J., Svobodová, I., Vaníčková, M. \& Tančin, V. (2012). Analysis of Slovak and Czech national breeds of geese with respect to effective population size. Slovak Journal of Animal Science 45, 43-47. Kadlečík, O., Halo, M., Chmelničná, L., Weis, J., Kasarda, R., Mindek, S. Margetin, M., Bullová, M., Kopernický, M., Chlebo, R., Hrnčár, C., Svetlik, I \& Hubka, M. (2004). Endangered breeds of animal in Slovakia. Nitra: Slovak University of Agricultural in Nitra 100 p. [in Slovak]

Kleven, O., Kroglund, R.T. \& Østnes, J.E.J. (2016). Isolation, characterization and multiplex PCR development of Bean Goose (Anser fabalis) microsatellite loci. Journal of Ornithology, 157, 641. https://doi.org/10.1007/s10336-015-1309-z

Laval, G., Iannuccelli, N., Legault, C.H., Milan, D., Groenen, M.A.M., Giuffra E., Andersson, L., Nissen, P.H., Jorgensen, C.B., Beeckmann, P., Geldermann, H., Foulley, J.L., Chevalet, C. \& Ollivier, L. (2000). Genetic diversity of eleven European pig breeds. Genetics Selection Evolution, 2, 187-203. https://doi.org/10.1051/gse:2000113

Larivière, J.M., Detilleux, J. \& Leroy, P. (2011). Estimates of inbreeding rates in forty traditional Belgian chicken breeds populations. Archiv Fur Geflugelkunde, 75, 1-6.

Lawson-Handley, L.J., Byrne, K., Santucci, F., Townsend, S., Taylor, M. Bruford, M. W. \& Hewitt, G.M. 2007. Genetic structure of European sheep breeds. Heredity, 99, 620-631. https://doi.org/10.1038/sj.hdy.6801039

Lenstra, J.A., L.F. Goeneveld, H. Eding, J.L. Kantanen, J.L. Williams, P. Taberlet, E.L. Nicolazzi, J. Solkner, H. Simianer, E. Ciani, J.F. Garcia, M.W. Bruford, P. Ajmone-Marsan, and S. Weigend. 2012. Molecular tools and analytical approaches for the characterization of farm animal genetic diversity. Animal Genetics 43:483-502. https://doi.org/10.1111/j.1365-2052.2011.02309.x 
Li, H.F., K.W. Chen, N. Yang, W.T. Song, and Q.P. Tang. 2007. Evaluation of genetic diversity of Chinese native geese revealed by microsatellite markers. World's Poultry Science Journal 63:381-390.

Liu, K. and S.V. Muse. 2005. PowerMarker: Integrated analysis enviroment for genetic marker data. Bioinformatics 21:21282129. https://doi.org/10.1093/bioinformatics/bti282

Liu, S., P. Li, Y. Song, S.Z. Li, C.B. Wie, and H.M. Yang. 2006. Analysis of genetic variations in different goose breeds using microsatellite markers. Yi Chuan 28:1389-1395.

Lynch, M., Conery, J. and R. Burger. 1995. Mutation accumulation and the extinction of small populations. American Naturalist 146: 489-518.

Meuwissen, T.H.E. and J.A. Wooliams. 1994. Effective sizes of livestock populations to prevent a decline in fitness. Theoretical and Applied Genetics, 89: 1019-1026. https://doi.org/10.1007/bf00224533

Mindek, S. 2001. The use the original and the foreign germplasm of geese in creating an appropriate type of goose for large scale conditions. Ph.D. Thesis, Slovak University of Nitra.

Nie, M. 1978. Estimation of average heterozygosity and genetic distance from a small number of individuals. Genetics 89: 583-590.

Nomura,T. and K. Yonezawa. 1996. A comparison of four systems of group mating for avoiding inbreeding. Genetic Selection Evolution 28: 141-159. https://doi.org/10.1051/gse:19960202

Noreikiene, K., A.G.F. Teacher, J. Madsen and P. Gienapp. 2012. Isolation and characterization of 55 novel microsatellite markers for the pink-footed goose (Anser brachyrhynchus). Conservation Genetics Resources 2:423-428. https://doi.org/10.1007/s12686-011-9565-6

Peakall, R. and P.E. Smouse. 2006. GENALEX 6: genetic analysis in Excel. Population genetic software for teaching and research. Molecular Ecology Notes 6: 288-295. https://doi.org/10.1111/j.1471-8286.2005.01155.x

Rakotomalala, R. 2005. TANAGRA: un logiciel gratuit pour l'enseignement et la recherche". Actes de EGC'2005 2: 697-702.

Romanov, M.N., S. Wezyk, K. Cywa-Benko, and N.I. Sakhatsky. 1996. Poultry genetic resources in the countries of Eastern Europe - history and curent state. Poultry Avian Biology 7:1-29.

Rousset, F. 2008. Genepop'007: a complete reimplementation of the Genepop software for Windows and Linux. Molecular Ecology Resources 8: 103-106. https://doi.org/10.1111/j.1471-8286.2007.01931.x

Simianer, H. 2006. Use of molecular markers and other information for sampling germplasm to create an animal gene bank. The role of biotechnology in exploring and protecting agricultural genetic resources: FAO, p. 81-96.

Simon, D. L. and D. Buchenauer. 1993. Genetic diversity of European livestock breeds. Wageningen, $581 \mathrm{p}$.

Takezaki, N., M. Nei, and K. Tamura. 2010. POPTREE2: Software for constructing population trees from allele frequency data and computing other population statistics with Windows interface. $\begin{array}{lllll}\text { Molecular Biology and } & \text { 747-752. }\end{array}$ https://doi.org/10.1093/molbev/msp312

Tu, Y.J., K.W. Chen, S.J. Zhang, Q.P. Tang, S. Gaoy, and N. Yang. 2006. Genetic diversity of 14 indigenous grey goose breeds in China based on microsatellite markers. Asian- Australasian Journal of Animal Sciences 19: 1-6. https://doi.org/10.5713/ajas.2006.1

Wang, J. 1997. More efficient breeding systems for controlling inbreeding and effective population size in animal populations. Heredity 157: 591-599.

Wang, J., Hill, W.G., Charlesworth, D. and B. Charlesworth, 1999. Dynamics of inbreeding depression due to deleterious mutations in small populations: mutation parameters and inbreeding rate. Genetical Research 74: 165-178.

Weir, B.S. 1996. Genetic Data Analysis II. Sinauer Associates, Massachusetts: Publishers Sunderland, p. 376.

Weis, J. and C. Hrnčár. 2007. The biodiversity of poultry national breeds of geese breeding on area of the Slovakia. Acta fytotechnica et zootechnica 10: 85-87. [in Slovak]

Weis, J., I. Gardiánová, C. Hrnčár, S. Mindek, L. Jebavý, and J. Bujko. 2010. Frequency analysis of national goose breeds under the conditions of the Slovak Republic. Acta fytotechnica et zootechnica 13:28-30. [in Slovak]

Weiß, B.M, K. Poggemann, K. Olek, K. Foerster, and K. Hirschenhauser. 2008 Isolation and characterization of microsatellite marker loci in the greylag goose (Anser anser). Molecular Ecology Resources 8: 1411-1413. https://doi.org/10.1111/j.1755-0998.2008.02339.x

Wilkinson, S., P. Wiener, D. Teverson, C.S. Haley, and P.M. Hocking. 2012 Characterization of the genetic diversity, structure and admixture of British chicken breeds. Animal Genetics 43: 552-563. https://doi.org/10.1111/j.1365$\underline{2052.2011 .02296 . x}$ 